\title{
Analisis Kemandirian Belajar Siswa pada Mata Pelajaran Biologi Kelas X SMA YKPP Pendopo
}

\author{
Analysis of Student Learning Independence in Biology Class X YKPP Pendopo High School
}

\author{
Sesi Oktarin ${ }^{1 *}$, Lia Auliandari ${ }^{1}$, Tutik Fitri Wijayanti ${ }^{1}$ \\ ${ }^{1}$ Pendidikan Biologi FKIP Universitas Muhammadiyah Palembang \\ * Email Korespondensi: Sesioktarin31@gmail.com
}

doi: https://doi.org/10.29405/j.bes/22104-1152493

Received: 6 Oktober 2018 | Accepted: 1 Desember 2018 | Published: 31 Desember 2018

\section{Abstrak}

Background: Kemandirian menjadi salah satu faktor internal yang mempengaruhi keberhasilan belajar siswa, melalui kemandirian belajar akan membawa perubahan sikap serta perubahan positif dalam setiap tindakan siswa. Tujuan penelitian ini bertujuan untuk menganalisis kemandirian belajar siswa pada mata pelajaran biologi kelas X SMA YKPP Pendopo. Metode: Metode penelitian termasuk deskriptif kuantitatif. Teknik sampling menggunakan teknik sampling jenuh, dengan subjek penelitian ialah kelas X.IPA 1 dan X.IPA 2 SMA YKPP Pendopo. Instrumen dalam penelitian menggunakan angket sebagai data primer dan lembar observasi yang digunakan untuk mengambil data sekunder pada saat pengamatan kegiatan-kegiatan kemandirian belajar siswa. Angket yang digunakan berupa angket dengan skala bertingkat. Teknik analisis data menggunakan model Rasch melalui program Winsteps untuk menganalisis Person Item Map, Person Fit Order, Scalogram, dan Person Measure. Hasil: Hasil penelitian menunjukkan bahwa dari 72 responden terdapat 63 siswa yang memiliki kemandirian yang tinggi dan termasuk valid dengan nilai logit di atas 0,00, kemudian 3 siswa yang memiliki kemandirian yang rendah dengan nilai logit di bawah 0,00 dan 6 siswa dinyatakan tidak valid dikarenakan tidak memenuhi kriteria misfit. Kesimpulan: Siswa kelas X SMA YKPP Pendopo memiliki kemandirian yang tinggi dengan persentase sebesar $87,5 \%$. Kemandirian belajar siswa yang tinggi ditunjukkan dari kecenderungan siswa yang lebih banyak menyetujui item pernyataan pada angket, yaitu pada indikator tanggung jawab yang didukung dari hasil observasi bahwa sebesar $62,5 \%$ siswa selalu menunjukkan sikap tanggung jawab dan sebesar 44,43\% siswa selalu menunjukkan sikap disiplin.

Kata kunci: Kemandirian belajar siswa, Mata pelajaran biologi, Siswa SMA

\section{Abstract}

Background: Independence is one of the internal factors that influence the success of student learning, through learning independence will bring changes in attitudes and positive changes in each student's actions. This study aims to analyze the learning independence of students in biology subject of $X$ class in SMA YKPP Pendopo. Methods: Research methods include quantitative descriptive. The sampling technique uses saturated sampling technique, with the research subject is class X.IPA 1 and X.IPA 2 SMA YKPP Pendopo. Instruments in the study used questionnaires as primary data and observation sheets used to retrieve secondary data at the time of observation of student learning independence activities. The questionnaire used was a multilevel scale questionnaire. The data analysis technique uses the Rasch model through the Winsteps program to analyze Person Map Items, Person Fit Orders, Scalograms, and Person Measure. Results: The results of the study showed that from 72 respondents there were 63 students who had high independence and included valid with a logit value above 0.00, then 3 students who had low independence had logit values below 0.00 and 6 students were declared not valid because it does not meet the criteria of misfit. Conclusions: Student of X class in SMA YKPP Pendopo have high independence with a percentage of $87.5 \%$. Students' high learning independence is shown by the tendency of students to agree more on statement items on the questionnaire, namely on the indicator of responsibility supported by observations that $62.5 \%$ of students always show an attitude of responsibility and as much as $44.43 \%$ students always show attitude discipline.

Keywords: Student Learning Independence, Biology Subject, Senior High School Students 
Cara Sitasi: Oktarin, S., Auliandari, L., Wijayanti, T.F. 2019. Analisis Kemandirian Belajar Siswa pada Mata Pelajaran Biologi Kelas X SMA YKPP Pendopo. BIOEDUSCIENCE, 2(2): 104-115. Doi: https://doi.org/10.29405/j.bes/22104-1152493

\section{(c) (i)}

(C) 2018 Oleh authors. Lisensi Bioeduscience, Uhamka, Jakarta. Artikel ini bersifat open access yang didistribusikan di bawah syarat dan ketentuan Creative Commons Attribution (CC BY) license. (http://creativecommons.org/licenses/by/4.0/)

\section{PENDAHULUAN}

Kemandirian menjadi salah satu faktor internal yang mempengaruhi keberhasilan belajar siswa (Mulyasa, 2006; Syahputra, 2016; Suryabrata, 2002). Hal ini ditunjukkan melalui penelitian Fudayanti (2011), bahwa kemandirian belajar mempunyai pengaruh positif dan mempunyai kontribusi terhadap prestasi belajar sebesar $18,8 \%$. Sama halnya seperti penelitian Sobri \& Moerdiyanto (2014) juga yang menunjukkan bahwa kemandirian berpengaruh positif sebesar $21,2 \%$ terhadap hasil belajar siswa. Selain itu, hasil belajar kognitif siswa pada pelajaran biologi dipengaruhi oleh kemandirian belajar siswa tersebut, yaitu sebesar 33,5\% (Rijal \& Bacthiar, 2015).

Siswa yang memiliki kemandirian belajar ditunjukkan dengan adanya sikap percaya diri, mampu mengambil keputusan, inisiatif, tanggung jawab, disiplin dan tidak bergantung kepada orang lain dalam kegiatan pembelajaran yang dilakukannya (Egok, 2016; Ismaya, 2013; Purnomo, 2016). Selain itu, kemandirian yang diterapkan oleh siswa kepada dirinya sendiri akan membawa perubahan yang positif terhadap intelektualitasnya yaitu mampu dalam menganalisis permasalahan yang kompleks, dapat menentukan tujuan belajarnya, sumbersumber yang digunakan untuk proses belajar dan strategi pencapaian tujuan belajarnya (Yamin, 2008).

Kemandirian belajar siswa yang membawa perubahan sikap serta perubahan positif dalam setiap tindakannya tidak terlepas dari adanya faktor-faktor yang mendasari terciptanya kemandirian belajar siswa. Faktor yang mendasari kemandirian belajar seorang siswa yaitu faktor dari dalam diri siswa dan faktor dari luar diri siswa itu sendiri (Basri, 2008). Faktor-faktor tersebut sangat menentukan tercapainya kemandirian belajar siswa.

Adapun faktor dari dalam diri siswa seperti niat dan motivasi yang kuat untuk mencapai tujuan pembelajaran. Hasil penelitian Kurniawan (2014) yang menunjukkan apabila motivasi belajar siswa meningkat maka kemandirian belajar yang dimiliki siswa semakin meningkat karena dorongan dari dalam diri siswa inilah yang membuat seseorang ingin bersikap mandiri, sedangkan untuk faktor dari luar diri siswa ialah adanya peran seorang guru dan penggunaan sumber belajar pada saat kegiatan pembelajaran.

Guru memiliki peran yang penting dalam kegiatan pembelajaran karena guru sebagai penanggung jawab kegiatan pembelajaran (Yamin \& Sanan, 2013). Salah satu peran seorang guru ialah dapat membantu siswa dalam melatih dan membiasakan siswa berperilaku mandiri pada setiap aktivitas kegiatan pembelajaran. Cara yang dapat digunakan seorang guru untuk melatih kemandirian belajar siswa ialah melalui metode atau model pembelajaran yang digunakan guru tersebut mengajar di dalam kelas, seperti membantu menciptakan ketertarikan siswa dan menimbulkan keaktifan siswa dalam kegiatan belajar, kemudian memberikan kebebasan siswa dalam mengemukakan pendapat atau mengerjakan tugas dengan cara mereka sendiri (Afril, 2006).

Kemandirian belajar masih menjadi fokus permasalahan dalam dunia pendidikan di 
Indonesia yang cukup memprihatinkan. Hasil penelitian Nahdliyati, et al (2016), Puspasari (2015), Siswanto (2016) dan Taupik, et al (2017) menunjukkan kemandirian belajar siswa dapat dikatakan dalam kategori rendah. Disinyalir rendahnya kemandirian belajar terjadi di sebagian besar sekolah di Indonesia.

Berdasarkan hasil wawancara bersama guru biologi di SMA YKPP Pendopo pada Januari 2018 bahwa beliau sudah berupaya dalam melatih kemandirian belajar siswa kelas $\mathrm{X}$ pada mata pelajaran biologi. Melatih kemandirian siswa kelas $\mathrm{X}$ terhadap proses pembelajaran biologi pertanyaan lisan terkait materi pelajaran kepada siswa, hal ini dimaksudkan agar siswa dilatih untuk mengungkapkan pendapatnya dan lebih mandiri dalam menjawab pertanyaan tanpa bergantung dengan temannya. Selain itu, dari hasil wawancara beliau mengatakan bahwa pada saat keadaan kelas tidak ditunggu maka beliau menyikapi hal ini dengan memberi tugas kepada siswa agar mereka tetap mendapatkan pelajaran.

Selain adanya peran seorang guru, kemandirian belajar siswa akan terbentuk dengan baik jika didukung dengan ketersediaan sumber belajar pada saat kegiatan pembelajaran seperti adanya buku pegangan Biologi siswa yang dapat digunakan pada saat proses pembelajaran biologi. SMA YKPP Pendopo merupakan sekolah swasta yang terakreditasi A yang memiliki kelengkapan sarana dan prasarana dalam menunjang kemandirian belajar siswa. Sarana dan prasarana tersebut ialah seperti tersedianya perpustakaan, laboratorium Biologi, buku pegangan siswa, serta alat-alat peraga yang mendukung siswa dalam melakukan proses pembelajaran di kelas maupun di laboratorium.

Hasil wawancara mengatakan bahwa guru biologi menggunakan buku pegangan paket dan bahan ajar lain seperti LKS yang dapat membantu kegiatan pembelajaran biologi. Beliau menambahkan bahwa siswa sudah diberikan fasilitas dari sekolah berupa buku pegangan paket biologi untuk digunakan di kelas. Beliau memanfaatkan LKS dalam memberikan tugas untuk dikerjakan siswa di dalam kelas, dimana untuk menunjang dalam mengerjakan LKS harus didukung dengan buku pegangan paket dan sumber belajar lain yang bisa siswa dapatkan di perpustakaan. Hal tersebut dapat melatih siswa mandiri dalam mengerjakan tugas tanpa harus bergantung dengan orang lain tetapi memanfaatkan sumber belajar serta fasilitas belajar yang disediakan dari sekolah.

Melihat hasil wawancara bersama guru biologi, seharusnya siswa kelas $\mathrm{X}$ sudah memiliki kemandirian dalam kegiatan pembelajaran biologi. hal tersebut dikarenakan sudah adanya upaya dari guru biologi dan penyediaan sumber belajar dari sekolah dalam melatih kemandirian belajar siswa. Penting untuk dianalisis kemandirian belajar siswa kelas $\mathrm{X}$ pada mata pelajaran biologi agar diketahui secara empiris mengenai kemandirian belajar siswa yang kemudian dengan mudah menentukan langkah selanjutnya dalam kegiatan pembelajaran untuk menumbuhkan kemandiran belajar siswa di kelas terhadap mata pelajaran biologi.

\section{MATERI DAN METODE}

Metode yang digunakan dalam penelitian ini adalah metode deskriptif kuantitatif. Dalam pelaksanaannya, penelitian ini bermaksud untuk mendapatkan data yang dapat digunakan untuk mendeskripsikan mengenai kemandirian belajar siswa kelas X

SMA YKPP Pendopo pada mata pelajaran biologi.

\section{Lokasi dan Waktu penelitian}

Penelitian ini dilaksanakan pada bulan Mei tanggal 09 Mei 2018 sampai dengan 15 Mei 2018. Lokasi penelitian dilaksanakan di SMA YKPP Pendopo tahun akademik 2017/2018.

\section{Populasi dan sampel}

Subjek dalam penelitian ini adalah siswa kelas X IPA SMA YKPP Pendopo yang 
berjumlah dua kelas dengan total 72 siswa yang termasuk ke dalam sampling jenuh. Kedua kelas masing-masing berjumlah 36 siswa kelas IPA 1 dan 36 siswa kelas IPA 2.

\section{Instrument Penelitian}

Instrumen dalam penelitian menggunakan lembar angket dan lembar observasi. Lembar angket digunakan untuk mengambil data primer dalam menganalisis kemandirian belajar siswa. Penggunaan angket bertujuan agar siswa mampu melakukan penilaian diri sendiri terkait kemandirian siswa pada saat pembelajaran biologi, sedangkan lembar observasi digunakan untuk mengambil data sekunder dalam menganalisis kemandirian belajar siswa. Lembar observasi digunakan pada saat pengamatan secara langsung kegiatan-kegiatan kemandirian belajar siswa berdasarkan indikator kemandirian belajar siswa yang telah ditentukan.

Lembar angket yang digunakan adalah berupa angket dengan skala bertingkat, yaitu berisikan pernyataan yang diikuti oleh kolomkolom yang menunjukkan suatu tingkatan, seperti selalu, sering, kadang dan tidak pernah. Lembar observasi dan lembar angket disusun oleh peneliti yang dimodifikiasi dari skripsi Astuti (2014), Fudayanti (2011) dan Masila (2017).

Jumlah butir item pernyataan pada angket sebanyak 24 item pernyataan, sedangkan jumlah butir item pernyataan pada lembar observasi ialah 15 item pernyataan. Kisi-kisi instrumen angket dapat dilihat pada Tabel 1 dan Kisi-kisi instrumen lembar observasi dapat dilihat pada Tabel 2.

Tabel 1. Kisi-kisi lembar observasi saat proses pembelajaran biologi

\begin{tabular}{llll}
\hline \multirow{2}{*}{ Indikator } & \multicolumn{2}{c}{ Nomor Item } & Jumlah \\
\cline { 2 - 3 } & \multicolumn{1}{c}{$(+)$} & \multicolumn{1}{c}{$(-)$} & \\
\hline Inisiatif & $1,6,18$ & 3,7 & 5 \\
Mampu mengambil & $5,8,9,19$, & 15 & 6 \\
keputusan & 14 & & \\
Tidak bergantung & 2 & 4,10 & 3 \\
kepada orang lain & & 12,13 & 3 \\
Tanggung jawab & 21 & 17 & 3 \\
Disiplin & 11,16 & 17
\end{tabular}

\begin{tabular}{lccc} 
Percaya diri & $20,22,23$ & 24 & 4 \\
Jumlah & 15 & 9 & 24 \\
\hline
\end{tabular}

Tabel 2. Kisi-kisi instrumen angket kemandirian belajar siswa

\begin{tabular}{|c|c|c|c|}
\hline \multirow{2}{*}{ Indikator } & \multicolumn{2}{|c|}{ Nomor Item } & \multirow{2}{*}{ Jumlah } \\
\hline & $(+)$ & $(-)$ & \\
\hline Inisiatif & 1 & 2,5 & 3 \\
\hline $\begin{array}{l}\text { Mampu mengambil } \\
\text { keputusan }\end{array}$ & 6,7 & 13 & 4 \\
\hline $\begin{array}{l}\text { Tidak bergantung } \\
\text { kepada orang lain }\end{array}$ & 3 & 4,8 & 3 \\
\hline Tanggung jawab & 11 & - & 1 \\
\hline Disiplin & 9,12 & 10 & 2 \\
\hline Percaya diri & 14 & 15 & 2 \\
\hline Jumlah & 8 & 7 & 15 \\
\hline
\end{tabular}

\section{Pengumpulan Data}

Teknik pengumpulan data yang digunakan dalam penelitian ini dilakukan melalui beberapa tahapan. Tahapan tersebut meliputi tahap persiapan, tahap pelaksanaan dan tahap penyelesaian.

1. Tahap persiapan, meliputi wawancara awal yang kemudian dilanjutkan dengan membuat instrumen penelitian dan melakukan uji instrumen penelitian.

2. Tahap pelaksanaan, peneliti akan melakukan observasi langsung pada subjek penelitian menggunakan lembar observasi dan membagikan angket kepada subjek penelitian untuk diisi.

3. Setelah peneliti selesai melakukan penelitian, maka langkah selanjutnya peneliti mengolah data hasil penelitian yang diperoleh.

\section{Analisis Data}

Angket yang digunakan dilakukan uji validitas dan reliabilitas menggunakan model Rasch. Teknik analisis data menggunakan model Rasch melalui program Winsteps untuk menganalisis Person Item Map, Person Fit Order, Scalogram, dan Person Measure.

1. Person Item Map yang dilakukan bertujuan untuk mengetahui tingkat kemandirian belajar siswa dan mengetahui tingkat kesulitan item pada angket. 
2. Person Fit Order dilakukan untuk mengetahui adanya siswa yang tidak memenuhi kriteria misfit.

3. Scalogram dapat mendeteksi adanya kecurangan siswa dalam menjawab angket, seperti mencontek pada saat pengisisan angket. Selain itu, dapat melihat bagaimana kecermatan siswa dalam menjawab angket dan dapat identifikasi adanya tebakan dari jawaban siswa

Analisis Person Measure bertujuan untuk mengetahui informasi nilai logit siswa dari yang tertinggi maupun yang terendah dan nilai logit yang sama antar siswa. Melalui rata-rata Person Measure dapat dilihat kecenderungan siswa yang lebih banyak menjawab setuju atau tidak setuju pada setiap item pernyataan angket

\section{HASIL}

\section{Hasil Analisis Angket Kemandirian Belajar Siswa}

Angket kemandirian belajar siswa yang sudah dinyatakan valid dan reliabel dengan jumlah 20 item pernyataan, selanjutnya diberikan kepada subjek penelitian. Setelah peneliti melakukan penelitian, selanjutnya peneliti melakukan analisis lebih lanjut dari hasil angket menggunakan model Rasch melalui program Winsteps untuk melihat hasil Person Item Map, Person Fit Order, Scalogram dan Person Measure. Berikut hasil analisis yang sudah dilakukan.

\section{Hasil Analisis Person Item Map}

Analisis Person Item Map dilakukan untuk mengetahui tingkat kemandirian belajar siswa pada kelas X SMA YKPP Pendopo. Hasil analisis Person Item Map dapat dilihat pada Gambar 1.

Gambar 1 menunjukkan tingkat kemandirian belajar siswa berdasarkan beberapa kriteria kemandirian belajar. Pengelompokan kriteria kemandirian belajar siswa dapat diketahui dari nilai Separation yang dilihat dari Summary Statistic pada Gambar 2.

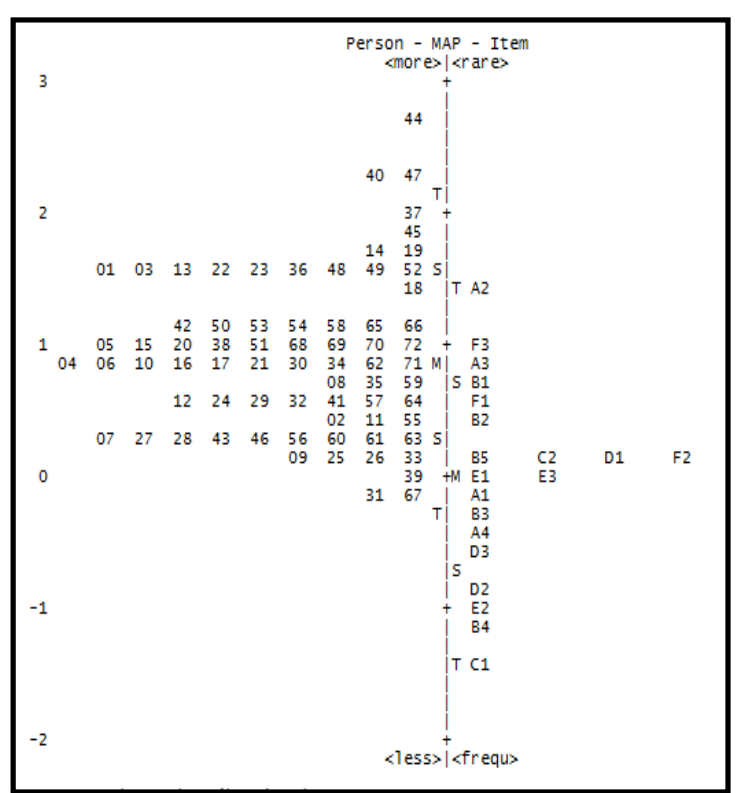

Gambar 1. Hasil analisis Person Item Map

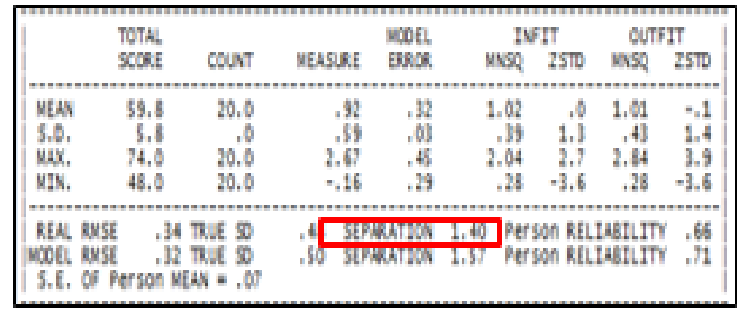

Gambar 2. Indeks Separation Person

Hasil indeks Separation Person yang didapatkan berdasarkan Gambar 2 ialah sebesar 1,40. Dengan indeks Separation 1,40, maka srata responden dalam penelitian ini dapat dilihat menggunakan rumus Person Srata (Sumintono \& Widhiarso, 2015), berikut:

$H=\frac{[(4 x \text { SEPARATION })+1]}{3}$

Keterangan:

H : Nilai Person Strata

SEPARATION : Nilai Separation untuk responden yang dihasilkan

Berdasarkan rumus Person Srata, maka $\mathrm{H}=[(4 \times 1,40)+1] / 3=2,2 . \quad$ Angka 2,2 dibulatkan menjadi 2, yang bermakna bahwa responden dibagi ke dalam dua kelompok besar, yaitu kelompok yang memiliki kemandirian belajar yang tinggi dan kemandirian belajar yang rendah. Gambar 1 menunjukkan bahwa adanya tiga siswa yang memiliki kemandirian belajar yang tergolong rendah, yaitu siswa 39, 
31 dan 67, sedangkan siswa yang memiliki kemandirian yang tinggi sebanyak 69 siswa.

$$
\text { Apabila ingin mengetahui }
$$

pengelompokan tingkat kesulitan item pada angket, maka dapat dilakukan dengan perhitungan menggunakan rumus yang sama, yaitu dengan melihat terlebih dahulu indeks Separation Item. Berikut nilai indeks Separation untuk item angket pada Gambar 3.

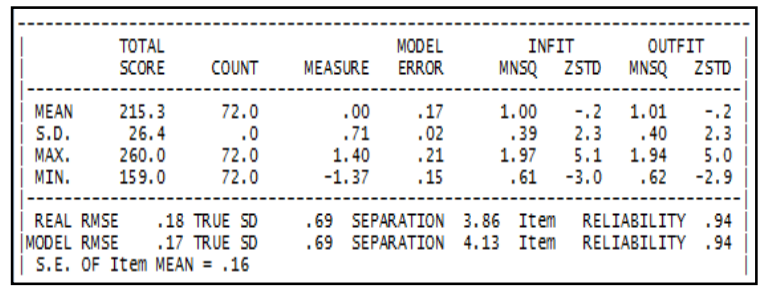

Gambar 3. Indeks Separation Item

Gambar 3 menunjukkan Separation Item pada angket yang memperoleh nilai sebesar 3,86. Dengan nilai indeks Separation Item 3,86, maka $\mathrm{H}=[(4 \times 3,86)+1] / 3=5,48$ (dibulatkan jadi 5). Hal tersebut menunjukkan bahwa terdapat 5 kelompok item berdasarkan tingkat kesulitannya untuk disetujui oleh responden, yaitu sangat mudah, mudah, sedang, sulit dan sangat sulit. Tingkat kesulitan item pernyataan pada angket dapat dilihat pada Tabel 3.

Tabel 3. Tingkat kesulitan item pernyataan pada angket

\begin{tabular}{ll}
\hline \multicolumn{1}{c}{ Kategori } & \multicolumn{1}{c}{ Nomor Item } \\
\hline Sangat mudah & $\mathrm{C} 1$ \\
Mudah & $\mathrm{D} 2, \mathrm{E} 2, \mathrm{~B} 4$, \\
Sedang & $\mathrm{B} 5, \mathrm{C} 2, \mathrm{D} 1, \mathrm{~F} 2, \mathrm{E} 1, \mathrm{E} 3$, \\
& $\mathrm{A} 1, \mathrm{~B} 3, \mathrm{~A} 4, \mathrm{D} 3$, \\
Sulit & $\mathrm{F} 3, \mathrm{~A} 3, \mathrm{~B} 1, \mathrm{~F} 1, \mathrm{~B} 2$ \\
Sangat sulit & $\mathrm{A} 2$ \\
\hline Keterangan: (A, B, C, D, E, F= Indikator Kemandirian \\
Belajar; 1, 2, 3, 4, 5 = Nomor item pernyataan)
\end{tabular}

\section{Hasil Analisis Person Fit Order}

Setelah diketahui tingkat kemandirian belajar siswa berdasarkan Person Item Map yang didapatkan hasil bahwa dari 72 responden terdapat 69 siswa yang memiliki kemandirian yang tinggi, selanjutnya peneliti melihat nilai Person Fit Order masing-masing siswa yang memiliki kemandirian yang tinggi untuk mengetahui jika ada siswa yang tidak memenuhi kriteria misfit. Hasil analisis Person Fit Order dilihat pada Tabel 4.

Tabel 4. Jumlah siswa dengan kategori tidak fit

\begin{tabular}{ccccc}
\hline \multirow{3}{*}{$\begin{array}{c}\text { No. } \\
\text { Siswa }\end{array}$} & $\begin{array}{c}\text { Outfit } \\
\text { MNSQ }\end{array}$ & $\begin{array}{c}\text { Outfit } \\
\text { ZSTD }\end{array}$ & $\begin{array}{c}\text { Pt } \\
\text { Measure } \\
\text { Corr }\end{array}$ & \\
\hline 48 & 2,84 & 3,9 & 0,07 & Tidak Fit \\
55 & 2,03 & 2,9 & 0,12 & Tidak Fit \\
35 & 1,87 & 2,5 & $-0,39$ & Tidak Fit \\
69 & 1,84 & 2,4 & 0,40 & Tidak Fit \\
70 & 1,84 & 2,4 & 0,40 & Tidak Fit \\
65 & 1,57 & 1,7 & $-0,04$ & Tidak Fit \\
\hline
\end{tabular}

Tabel 4 menunjukkan bahwa dari 69 siswa yang memiliki kemandiran yang tinggi didapatkan 6 siswa yang dinyatakan tidak fit karena tidak memenuhi kriteria misfit, sehingga untuk siswa yang memiliki kemandirian yang tinggi dan termasuk fit berjumlah 63 siswa. Siswa yang tidak memenuhi kriteria misfit dikarenakan memiliki pola respon yang berbeda. Pola respon yang berbeda adalah adanya ketidaksesuaian jawaban yang diberikan responden berdasarkan dengan tingkat kemandiriannya.

Siswa nomor 48 tidak memenuhi dua kriteria misfit. Hal tersebut dapat dilihat dari nilai outfit MNSQ sebesar 2,84 yang melebihi batas diterima dan nilai outfit ZSTD sebesar 3,9 yang juga melebih batas diterima. Begitupula dengan siswa 55, 69, 70, dan 65 yang tidak memenuhi dua kriteria misfit karena memiliki nilai Outfit MNSQ dan Outfit ZSTD diluar batas yang diterima, sedangkan siswa 35 tidak memenuhi ketiga kriteria misfit.

\section{Scalogram}

Adanya siswa yang termasuk kriteria misfit, maka peneliti menggunakan skalogram untuk melihat pola jawaban siswa yang tidak fit agar diketahui lebih jauh penyebab siswa yang tidak fit. Berikut hasil dari skalogram pada Tabel 5.

Tabel 5. Hasil pola jawaban siswa yang tidak fit

\begin{tabular}{cc}
\hline Nomor Siswa & Pola Jawaban Siswa \\
\hline 48 & 41444434444143333343 \\
\hline
\end{tabular}




\begin{tabular}{ll}
\hline 55 & 13433234232434233141 \\
35 & 32324233322243243434 \\
69 & 44422444434214432123 \\
70 & 44422444434214432123 \\
65 & 43342323244443223434 \\
\hline
\end{tabular}

Keterangan:

*Urutan pola dimulai dari yang terendah sampai tertinggi (C1, B4, E2, D2, D4, A4, B3, A1, E1, E3, B5, C2, D1, F2, B2, F1, B1, A3, F3, A2).

Berdasarkan Tabel 5 bahwa ada sejumlah responden yang memiliki pola respon yang tidak konsisten. Hasil pola jawaban siswa nomor 55, disamping tidak memiliki kecermatan karena tidak bisa menyetujui item C1 yang tergolong sangat mudah disetujui, namun dapat menyetujui item yang sulit disetujui pada item F3 yang tingkat kesulitannya lebih tinggi dari nilai logit siswa. Hal tersebut. mengindikasikan adanya unsur tebakan siswa dalam menjawab angket. Selain adanya pola yang tidak konsisten pada beberapa responden, ternyata juga didapatkan adanya pola jawaban yang sama antar responden. Hal ini ditunjukkan pada siswa nomor 69 dan 70 . Pola jawaban yang sama antar siswa 69 dan 70 mengindikasikan bahwa siswa hanya mencontek dalam mengisi angket yang diberikan oleh peneliti.

Jika dilihat dari analisis Person Reliability bahwa konsistensi jawaban siswa secara keseluruhan termasuk kategori lemah dengan nilai sebesar 0,66. Berikut hasil Person Reliability pada Gambar 4.

\begin{tabular}{|c|c|c|c|c|c|c|c|c|}
\hline \multirow{2}{*}{9} & \multirow{2}{*}{$\begin{array}{l}\text { POTAL } \\
\text { scok: }\end{array}$} & \multirow[b]{2}{*}{ CONT } & \multirow[b]{2}{*}{ WEASWRE } & \multirow{2}{*}{ 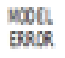 } & \multicolumn{2}{|c|}{ 2NIT } & \multicolumn{2}{|c|}{ क्या: } \\
\hline & & & & & UNSQ & 2510 & NISA & 2510 \\
\hline NEAN & 59.8 & 20.0 & .92 & .32 & 1.02 & .0 & 1.01 &,- 1 \\
\hline 5.0. & 5,8 & .0 & .59 & .03 & .39 & 1.1 &., 43 & 1.4 \\
\hline vax. & 74.0 & 20.0 & 2.67 & .45 & 2.04 & 2.7 & 2.84 & 3.9 \\
\hline KIN. & 48.0 & 20.0 & -.16 & .29 & .28 & -3.6 & .28 & -3.6 \\
\hline REA, NUSE & & R.t $\$$ & , 4556 & atraso & 1.420 & Filkts & ThIm & .w \\
\hline $\begin{array}{l}\text { WOOE, RUSE } \\
\text { S.E. OF P }\end{array}$ & Person & $\begin{array}{l}\text { R.E. } \$ D \\
S=.07\end{array}$ & .50 SEP & QATIDo & & & 70 & 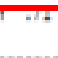 \\
\hline
\end{tabular}

Gambar 4. Hasil Person Reliability

Ketentuan untuk kategori Person Reliability siswa berdasarkan klasifikasi nilai Person Reliability Sumintono \& Widhiarso (2015). Berikut klasifikasi Person Reliability pada Tabel 6.
Tabel 6. Klasifikasi nilai Person Reliability

\begin{tabular}{cc}
\hline Nilai Person & Klasifikasi \\
Reliability & Lemah \\
\hline$<0,67$ & Cukup \\
$0,67-0,80$ & Bagus \\
$>0,80-0,90$ & Bagus sekali \\
$0,91-0,94$ & Istimewa \\
$>0,94$ &
\end{tabular}

(Sumber: Sumintono dan Widhiarso, 2015).

\section{Hasil Analisis Person Measure}

Rata-rata Person Measure diperoleh nilai sebesar 0,92 yang menunjukkan kecenderungan siswa yang lebih banyak menyetujui item pernyataan pada angket. Tingginya nilai ratarata Person Measure di atas 0,00 artinya semakin banyak siswa yang menjawab setuju dan apabila nilai rata-rata Person Measure di bawah 0,00 , maka menunjukkan jawaban siswa yang tidak setuju.

\section{Hasil Analisis Angket Lembar Observasi}

Lembar observasi yang digunakan dalam penelitian ini menjadi data penunjang terhadap kemandirian belajar siswa dengan cara melakukan pengamatan di dalam kelas pada saat kegiatan pembelajaran biologi sedang berlangsung. Pengamatan dilakukan dengan dibantu oleh 4 observer, selain itu untuk memudahkan observer mengamati siswa, maka peneliti memberikan nomor bahu kepada masing-masing siswa. Hasil analisis persentase siswa berdasarkan lembar observasi dapat dilihat pada Tabel 7 .

Tabel 7. Hasil analisis persentase lembar observasi

\begin{tabular}{lcccc}
\hline \multirow{2}{*}{ Indikator } & \multicolumn{4}{c}{ Persentase Masing-masing Skor } \\
\cline { 2 - 5 } & Selalu & Sering & Kadang & $\begin{array}{c}\text { Tidak } \\
\text { Pernah }\end{array}$ \\
\hline Inisiatif & $21,76 \%$ & $41,66 \%$ & $13,89 \%$ & $22,69 \%$ \\
$\begin{array}{l}\text { Mampu } \\
\text { mengambil }\end{array}$ & $24,54 \%$ & $41,67 \%$ & $21,76 \%$ & $12,03 \%$ \\
$\begin{array}{l}\text { keputusan } \\
\text { Tidak } \\
\text { bergantung } \\
\text { pada orang }\end{array}$ & $36,11 \%$ & $44,90 \%$ & $18,06 \%$ & $0,93 \%$ \\
lain & & & & \\
$\begin{array}{l}\text { Tanggung } \\
\text { jawab }\end{array}$ & $62,5 \%$ & $20,83 \%$ & $16,67 \%$ & $0 \%$ \\
$\begin{array}{l}\text { Disiplin } \\
\text { Percaya diri }\end{array}$ & $13,21 \%$ & $45,13 \%$ & $37,5 \%$ & $4,16 \%$ \\
\hline
\end{tabular}


Tabel 7 menunjukkan persentase dari setiap skor yang didapatkan siswa pada masingmasing indikator. Sebanyak $41,66 \%$ siswa sering menunjukkan sikap inisiatif pada saat kegiatan pembelajaran biologi, kemudian sebanyak $41,67 \%$ siswa sering menunjukkan sikap mengambil keputusan, sebanyak 44,90\% siswa sering menunjukkan sikap tidak bergantung pada orang lain pada saat kegiatan pembelajaran biologi sedang berlangsung, sebanyak $62,5 \%$ siswa selalu menunjukkan sikap tanggung jawab, kemudian sebanyak $44,43 \%$ siswa selalu menunjukkan sikap disiplin dan 45,13\% siswa kecenderungan sering menunjukkan sikap percaya diri.

\section{PEMBAHASAN}

\section{Kemandirian Belajar Siswa SMA YKPP Pendopo}

Berdasarkan hasil analisis dengan menggunakan pemodelan Rasch, diketahui bahwa terdapat dua kriteria kemandirian belajar siswa, yaitu siswa yang memiliki kemandirian belajar yang tinggi dan kemandirian belajar yang rendah. Pengelompokan kemandirian belajar siswa tersebut berdasarkan perhitungan menggunakan rumus Person Srata yang sudah dilakukan sebelumnya, sehingga dari 72 responden kelas X SMA YKPP Pendopo terdapat 69 siswa yang termasuk kelompok dengan kemandirian belajar tinggi, sedangkan siswa yang memiliki kemandirian belajar yang rendah berjumlah 3 siswa.

Jika dilihat dari Person Item Map bahwa untuk indikator yang menunjukkan banyaknya siswa mampu menyetujui atau mampu melakukan berdasarkan item angket adalah pada indikator disiplin, dengan kode item E1, E2 dan E3. Item-item pernyataan pada indikator disiplin tersebut merupakan item yang memiliki tingkat kesulitan sedang (E1, E3) dan mudah disetujui (E2), sehingga banyak siswa yang mampu menyetujui setiap item pernyataan indikator disiplin.
Banyaknya siswa yang mampu menyetujui item-item pernyataan pada indikator disiplin turut ditunjukkan dari hasil observasi yang menggunakan lembar observasi. Hasil lembar observasi menunjukkan bahwa sebanyak $44,43 \%$ siswa selalu menunjukkan sikap disiplin dan sebanyak 39,69\% siswa sering melakukan sikap disiplin pada saat proses pembelajaran biologi sedang berlangsung (Tabel 7).

Kemandirian sangat erat kaitannya dengan nilai disiplin, dimana apabila siswa memiliki sikap disiplin, tentu ia akan tahu apa kewajibannya sebagai pelajar yaitu belajar, sehingga ia akan memiliki kesadaran diri yang tinggi untuk belajar dengan tekun dan gigih untuk mencapai tujuan belajarnya berusaha untuk mendapatkan hasil belajar yang baik (Melvin, 2007). Kemandirian belajar sebagai suatu kemampuan yang ada dalam setiap diri siswa yang berkembang karena adanya sikap disiplin.

Kedisiplinan yang dilakukan siswa dalam kegiatan belajar akan dapat menciptakan keteraturan dan ketertiban sehingga kegiatan belajar menjadi lebih kondusif dan berjalan dengan lancar. Apabila kegiatan berjalan dengan lancar, maka keberhasilan belajar akan mudah dicapai, prestasi belajar siswa juga akan lebih mudah tercapai (Handani, 2014).

Siswa memerlukan kedisiplinan dalam belajarnya, namun seringkali siswa mengabaikan hal-hal mengenai kedisiplinan belajar, akibatnya siswa gagal dalam mencapai hasil belajar yang optimal. Bila siswa dapat mendisiplinkan diri, maka siswa tersebut memiliki waktu yang efisien dalam belajar. Seperti halnya yang telah diungkap (Danim, 2011), belajar yang efisien menuntut kedisiplinan belajar yang tinggi terutama disiplin diri, yaitu kemampuan memposisikan diri, kontrol diri dan konsistensi diri untuk bertindak.

Indikator yang menunjukkan sulitnya disetujui oleh sebagian siswa untuk dilakukan adalah indikator percaya diri, dengan kode item F1, F2 dan F3. Item-item pernyataan pada 
indikator percaya diri tersebut merupakan item yang termasuk kriteria sulit disetujui (F1, F3) dan sedang (F2). Sulitnya siswa dalam menyetujui setiap item pernyataan pada indikator percaya diri turut ditunjukkan dari hasil observasi bahwa pada indikator percaya diri hanya $13,21 \%$ yang selalu menunjukkan sikap percaya diri dan sebanyak $37,5 \%$ siswa kadang melakukan sikap percaya diri (Tabel 7).

Kemandirian belajar dapat dilaksanakan oleh siswa apabila siswa tersebut memiliki kepercayaan diri, karena sikap kemandirian pada umumnya dipengaruhi oleh self reliance atau kepercayaan diri yang dimiliki oleh siswa tersebut (Darmawan, 2013; Pratiwi \& Laksimiwati, 2016). Kepercayaan memberikan pandangan positif kepada siswa terhadap kemampuan dirinya untuk meningkatkan kemandirian belajar.

Kepercayaan diri menjadi salah satu faktor penting dalam pencapaian kemandirian belajar pada siswa. Siswa yang memiliki kepercayaan diri akan yakin dengan berbagai keputusan yang diambil untuk mencapai hasil belajar yang didapatkannya. Apabila siswa tidak memiliki kepercayaan diri, maka tidak dapat menumbuhkan sikap kemandirian belajar dalam dirinya. Oleh karena itu, siswa yang memiliki kepercayaan diri umumnya mampu memiliki keyakinan bahwa apapun langkah yang ditempuh dalam kegiatan belajarnya mampu memberikan hasil yang memuaskan nantinya (Komara, 2016).

Jika dilihat dari rata-rata Person Measure yang mencapai 0,92 artinya bahwa siswa banyak memberikan jawaban yang setuju pada setiap item pernyataan angket. Banyaknya jawaban siswa yang mudah menyetujui item yang sulit menandakan bahwa siswa tersebut mampu melakukan berdasarkan item pernyataan pada angket. Item yang sangat sulit disetujui oleh siswa untuk dilakukan ialah item A2. Item A2 yang termasuk ke dalam indikator inisiatif dengan pernyataan "Saya memiliki buku biologi tambahan selain buku yang diarahkan guru".

Item A2 sangat sulit disetujui oleh siswa karena pada pernyataan item A2 menunjukkan suatu kondisi yang menegaskan bahwa siswa memang sudah memiliki buku biologi tambahan selain buku yang diarahkan guru. Sulitnya siswa menyetujui item A2 disebabkan karena pada dasarnya siswa tidak memiliki buku biologi tambahan selain yang diarahkan guru. Hal tersebut juga terlihat dari hasil observasi bahwa masih banyaknya siswa yang tidak memiliki referensi sumber belajar yang lain selain buku pegangan biologi dari guru.

Terkait penggunaan sumber belajar yang digunakan oleh siswa, maka hal ini harus diperhatikan lagi oleh guru agar siswa memiliki banyak referensi sumber belajar yang akan memberikan mereka kemudahan dalam mengerjakan tugas-tugas yang diberikan oleh guru. Kemandirian belajar siswa akan membuat ia berusaha mencari sumber belajar yang lain, seperti buku yang akan membantu ia memahami suatu pelajaran yang belum dimengerti sebelum bertanya kepada guru pada saat proses pembelajaran berlangsung (Bunandar, 2016).

Item yang termasuk kategori sangat mudah disetujui oleh siswa yaitu item $\mathrm{C} 1$ yang termasuk indikator tidak bergantung pada orang lain dengan pernyataan "Saya mengandalkan buku biologi milik teman saya". Pada pernyataan item $\mathrm{C} 1$ yang termasuk pernyataan negatif menunjukkan banyak siswa yang memberikan respon tidak pernah mengandalkan buku milik temannya. Hal tersebut menandakan bahwa siswa sudah memiliki kemandirian belajar agar tidak bergantung kepada orang lain, begitupula dari hasil observasi yang menunjukkan sebanyak 44,90\% siswa sering menunjukkan sikap tidak bergantung pada orang lain saat proses pembelajaran biologi sedang berlangsung.

\section{Validitas dan Konsistensi Jawaban Siswa}

Adanya 6 siswa yang dinyatakan tidak valid disebabkan karena tidak memenuhi kriteria misfit yang sudah ditentukan sebelumnya, sehingga dari 69 siswa yang memiliki kemandiran yang tinggi dan termasuk valid ialah hanya berjumlah 63 siswa dengan 
persentase sebesar $87,5 \%$, kemudian siswa yang memiliki kemnadirian yang rendah berjumlah 3 siswa dengan persentase sebesar $4,17 \%$ dan $8,33 \%$ siswa dinyatakan tidak valid. Siswa yang tidak memenuhi kriteria misfit karena adanya ketidaksesuaian jawaban yang diberikan responden dalam mengisi angket berdasarkan dengan tingkat kemandiriannya, selain itu jika dilihat secara keseluruhan terkait dengan konsistensi jawaban siswa bahwa siswa memiliki konsistensi jawaban kategori lemah dengan nilai Person Reliability yang didapatkan hanya 0,66. Lemahnya konsistensi jawaban siswa dapat ditunjukkan dari adanya 6 siswa yang memiliki pola jawaban yang tidak konsisten.

Sebagai contoh responden nomor 48 yang termasuk siswa dengan kemandirian yang tinggi, namun siswa tersebut memiliki pola jawaban yang tidak konsisten. Tidak konsistennya jawaban siswa nomor 48 karena siswa tersebut kurang cermat dalam menjawab item pernyataan pada angket. Siswa nomor 48 mendapatkan skor yang rendah untuk item pernyataan yang mudah disetujui, yaitu nomor B4 dengan pernyataan "Apabila ada soal yang sulit, maka saya berusaha mencari sumber lain untuk untuk membantu saya menyelesaikan tugas", tetapi justru mendapatkan skor yang lebih tinggi pada item pernyataan yang termasuk kategori sedang yaitu nomor F2 dengan pernyataan "Saya akan memberikan pendapat lain kepada teman atau kelompok lain apabila jawaban yang diungkapkan kurang tepat", padahal dalam pernyataan item B4 tidak ditentukan sumber yang harus siswa gunakan dalam membantu ia menyelesaikan tugas.

Kurang cermatnya siswa karena siswa yang kurang memahami maksud dari item pernyataan pada angket, sehingga untuk item yang termasuk kategori mudah untuk disetujui membuat siswa mendapatkan skor yang rendah, padahal bila siswa paham dalam maksud dari item pernyataan angket akan membuat siswa mendapatkan skor yang tinggi. Setiap responden yang memiliki keterbatasan kemampuan penalaran akan kesulitan untuk memahami butir pernyataan di dalam skala. Akibat kesalahan memahami pernyataan tersebut pola respons mereka kurang bisa dimodelkan dan menjadi tidak fit dan dinyatakan tidak valid (Aziz, 2015).

\section{KESIMPULAN}

Berdasarkan dari penelitian yang telah dilakukan dengan menggunakan instrumen angket, maka peneliti dapat menyimpulkan bahwa siswa kelas X SMA YKPP Pendopo memiliki kemandirian yang tinggi. Hal tersebut digambarkan dari hasil Person Item Map bahwa terdapat 63 siswa memiliki kemandirian yang tinggi dan termasuk fit dengan persentase sebesar $87,5 \%$.

Kemandirian belajar siswa yang tinggi ditunjukkan dari kecenderungan siswa yang lebih banyak menyetujui item pernyataan pada angket, yaitu pada indikator tanggung jawab yang didukung dari hasil observasi bahwa sebanyak $62,5 \%$ siswa selalu menunjukkan sikap tanggung jawab dengan item pernyataan siswa tidak menyelesaikan tugas yang diberikan guru (pernyataan negatif) dan sebesar 44,43\% siswa selalu menunjukkan sikap disiplin dengan item pernyataan siswa menyelesaikan dan mengumpulkan tugas biologi tepat waktu, siswa memperhatikan penjelasan guru dan siswa menimbulkan keributan saat mengerjakan tugas atau saat guru sedang menjelaskan materi pelajaran biologi (pernyataan negatif).

\section{REFERENSI}

Afril, G. (2006). Standar Nasional Pendidikan. Jakarta: Asa Mandiri.

Aziz, R. (2015). Aplikasi Model Rasch Dalam Pengujian Alat Ukur. Jurnal Psikologi Islam, 12(2), 01-13. Diakses dari http://repository.uinmalang.ac.id/470/1/aplikasi\%20model\%20rasch \%20pada\%20kesmen pada 28 juni 2018.

Basri, H. (2008). Remaja Berkualitas. Yogyakarta: Pustaka Belajar.

Bunandar, A. E. (2016). Analisis Kemandirian Belajar Siswa pada Mata Pelajaran Biologi di Kelas X Mas Al-Mustaqim Kubu Raya. Skripsi. Pontianak: FKIP Biologi Univesitas Muhammadiyah Pontianak. Diakses dari 
http://repository.unmuhpnk.ac.id/540 pada 22 Desember 2018.

Danim, S. (2011). Pengantar Pendidikan. Bandung: Alfabeta.

Depdiknas. (2003). Undang-Undang Nomor 20 Tahun 2003, Tentang Sistem Pendidikan Nasional. Jakarta: Depdiknas.

Egok, A. S. (2016). Kemampuan Berpikir Kritis dan Kemandirian Belajar dengan Hasil Belajar Matematika. Jurnal Pendidikan Dasar, 7(2), 185-198. Diakses dari http://pps.unj.ac.id/journal/jpd/article/view/379/3 29 pada 10 April 2018.

Fudayanti, F. E. (2011). Pengaruh Sumber Belajar dan Kemandirian Belajar Siswa Terhadap Prestasi Belajar Ekonomi Siswa Kelas X Madrasah Aliyah Negeri 1 PATI. Skripsi. Semarang: Fakultas Ekonomi Universitas Negeri Semarang. Diakes dari http://lib.unnes.ac.id/9708/1 pada 17 Februari 2018.

Handani, M. T. (2014). Pengaruh Kedisiplinan Belajar dan Pemanfaatan Fasilitas Belajar terhadap Prestasi Belajar Sosiologi Siswa Kelas XI IPS di SMA Batik 1 Surakarta. Skripsi. Surakarta: FKIP Sosiologi Universitas Sebelas Maret Surakarta. Diakses dari https://media.neliti.com/media/publications/ pada 18 April 2018.

Ismaya, R. (2013). Pengaruh Kemandirian Belajar, Cara Belajar dan Budaya Membaca Terhadap Hasil Belajar Ekonomi Siswa Kelas XI IPS SMA Perintis 2 Bandar Lampung. Jurnal Ekonomi dan Bisnis, 1(1), 1-12. Diakses dari http://digilib.unila.ac.id/5574 pada 18 Februari 2018.

Kurniawan, D. (2014). Hubungan Motivasi Belajar terhadap Kemandirian Belajar Siswa Kelas XI pada Kompetensi Mengidentifikasi Sistem Pengapian dan Komponennya Program Studi Keahlian Teknik Otomotif SMK Taman siswa Yogyakarta Tahun Ajaran 2013/2014. Skripsi. Yogyakarta: Pendidikan Teknik Otomotif Universitas Negeri Yogyakarta. Diakses dari HYPERLINK

"http://eprints.uny.ac.id/25978/1/Dhani\%20Kurn iawan-06504244039"

http://eprints.uny.ac.id/25978/1/Dhani\%20Kurniawan06504244039 pada 10 April 2018.

Komara, I. B. (2016). Hubungan antara Kepercayaan Diri dengan Prestasi Belajar dan Perencanaan Karir Siswa. Jurnal Psikopedagogia, 5(1), 34-40. Diakses dari

HYPERLINK "http://journal.uad.ac.id/index.php/PSIKOPEDA GOGIA/article/"

Http://Journal.Uad.Ac.Id/Index.Php/Psikopedagogia/A rticle/ pada 13 Juli 2018.
Mulyasa. (2006). Implementasi Kurikulum 2004 Panduan Pembelajaran KBK. Bandung: Remaja Posdakarya.

Nahdliyati, R., Parmin, M., \& Taufiq. (2016). Efektivitas Pendekatan Saintifik Model Project Based Learning Tema Ekosistem untuk Menumbuhkan Kemandirian Belajar Siswa SMP. Unnes Science Education Journal, 5(2), 20-32. Diakses dari HYPERLINK "http://journal.unnes.ac.id/sju/index.php/usej\%20 pada\%2010\%20April\%202018"

http://journal.unnes.ac.id/sju/index.php/usej pada 10 April 2018

Pratiwi, D. I., \& Laksimiwati, H. (2016). Kepercayaan Diri dan Kemandirian Belajar Siswa pada Siswa. Jurnal Psikologi Teori dan Terapan, 7(1), 43-49. Diakses dari https://journal.unesa.ac.id/index.php/jptt/article/v iewFile/1769/1187 pada 18 Maret 2018.

Puspasari, L. D. (2015). Peningkatan Kemandirian dan Hasil Belajar Matematika SMP Melalui Pendekatan Realistic Mathematics Education. Skripsi. Surakarta: FKIP Universitas Muhammadiyah Surakarta. Diakses dari http://eprints.ums.ac.id/24895/12/naskah_publika si.pdf pada 10 april 2018.

Purnomo, Y. (2016). Pengaruh Sikap Siswa pada Pelajaran Matematika dan Kemandirian Belajar Siswa Terhadap Prestasi Belajar Matematika. Jurnal Matematika, 2(1), 93-105. Diakses dari http://journal; lppmunindra.ac.id/index.php/jkpm/article/downl oad/1897/1478 pada 19 Februari 2018.

Rijal, S., \& Bacthiar, S. (2015). Hubungan Antara Sikap, Kemandirian Belajar dan Gaya Belajar dengan Hasil Belajar Kognitif Siswa. Jurnaal Bioedutika, 3 (2), 15-20. Diakses dari

http://journal.uad.ac.id/index.php/bioedukatika/articl e/view/4149 pada 20 Februari 2018.

Melvin, S. (2007). Active learning Startegi Pembelajaran Aktif. Yogyakarta: Pustaka Insani Madani.

Siswanto. (2016). Keterampilan Proses Sains Dan Kemandirian Belajar Siswa. Jurnal Ilmiah Penelitian dan Pembelajaran Fisika, 2(2), 10-28. Diakses dari http://jurnal.untirta.ac.id/index.php/Gravity pada 10 April 2018.

Sobri, M., \& Moerdiyanto. (2014). Pengaruh Kedisiplinan dan Kemandirian Belajar Terhadap Hasil Belajar Ekonomi Madrasah Aliyah di Kecamatan Praya. Jurnal Pendidikan IPS, 1(1), 5-22. Diakses dari https://journal.uny.ac.id/index.php/hsjpi/article pada 25 Februari 2018. 
Sumintono, B., \& Widhiarso, W. (2015). Aplikasi Pemodelan Rasch pada Assessment Pendidikan. Cimahi: Trim Komunikata Publishing House.

Suryabrata, S. (2002). Psikologi Pendidikan. Jakarta: PT. Grafindo Perkasa Rajawali.

Syahputra. (2016). Pengaruh Persiapan Belajar Siswa terhadap Prestasi Belajar Matematika pada Pokok Bahasan Kuadrat dan Akar Kuadrat Bilangan Bulat Siswa SMP Swasta Bandung Percut Sei Tuan. Jurnal manajeman dan Informatika Komputer Pelita Nusantara, 19(1), 79-83. Diakses dari http://ejurnal.pelitanusantara.ac.id/index.php/ma ntik/article/download/108/15 pada 10 Maret 2018.

Tahar, I., \& Eceng. (2006). Hubungan Kemandirian Belajar dan Hasil Belajar pada Pendidikan Jarak Jauh. Jurnal Pendidiakan Terbuka dan Jarak Jauh, 7 (2), 91-101. Diakses dari http://simpen.lppm.ut.ac.id/htmpublikasir pada 27 Januari 2018.

Taupik., Nuriah, T., \& Umasih. (2017). Pengaruh Metode Pembelajaran dan Kemandirian Belajar terhadap Sikap Siswa pada Pembelajaran Sejarah SMA Negeri 3 Karawang. Jurnal Pendidikan Sejarah, 7(2), 50-68. Diakses dari HYPERLINK "http://journal.unj.ac.id/unj/index.php/jps/article/ download/3534/2540/"

http://journal.unj.ac.id/unj/index.php/jps/article pada 10 April 2018.

Yamin, M. (2008). Teknik Mengembangan Kemampuan Inidividual. Jakarta: Gaud Persada Pres. 